\title{
Constitutional Rights of Infants and Toddlers to Have Opportunities to Form Secure Attachment with Incarcerated Mothers: Importance of Prison Nurseries
}

\author{
Naoki Kanaboshi ${ }^{1}$, James F. Anderson ${ }^{2}$, Natalia Sira ${ }^{3}$ \\ ${ }^{1}$ College of Community and Public Service, Assistant Professor of Criminal Justice, Grand Valley State University, Grand \\ Rapids, MI, USA. \\ ${ }^{2}$ College of Arts \& Sciences, Professor of Criminal Justice, East Carolina University, Greenville, NC, USA. \\ ${ }^{3}$ College of Health and Human Performance, Associate Professor of Human Development and Family Science, East \\ Carolina University, Greenville, NC, USA \\ Correspondence: James F. Anderson, Professor, Department of Criminal Justice, East Carolina University, Greenville, NC, \\ USA.
}

Received: November 29, 2016

Accepted: December 19, 2016

Available online: January 17, 2017

doi:10.11114/ijsss.v5i2.2160

URL: http://dx.doi.org/10.11114/ijsss.v5i2.2160

\begin{abstract}
While the number of women is increasing among the prison population, so too is the need to accommodate those who are pregnant and with children. Instead of examining the diminished rights of incarcerated mothers, this paper examines the rights of babies (infants and toddlers) to have opportunities to form a secure attachment with their incarcerated mother. This paper argues this right triggers the government's affirmative duty to provide prison nurseries. This paper also seeks several aims that include an examination of the issue of prison nurseries, the need for such programs, their history, the constitutional rights of infants and toddlers to have opportunities to form secure attachment with their long-term caregiver, and the policy implications for women or female prisons.
\end{abstract}

Keywords: incarcerated mothers, prison nurseries, rights of babies, secure attachment

\section{Introduction}

In the US, an estimated 2.2 million people are serving a sentence in the nation's jails and prisons, while another 4.7 million Americans are under some form of community supervision program (Kaeble, Glaze, Tsoutis, \& Minton, 2015). Current reports show that the incarceration rate represents a 500\% increase over the past thirty years (The Sentencing Project, 2015). Consequently, this trend has contributed to prison overcrowding that has resulted in nearly every state spending enormous sums of money to expand its correctional system. Despite the fact that crime rates have been dropping since the 1990s, the prison population continues to increase.

What is more alarming about the rising incarceration rate in the US is that women also factor prominently among those who are confined. Statistics show that in 2011, more than one million women were placed under some form of supervision by the criminal justice system (The Sentencing Project, 2012). Carson and Golinelli (2013) reported that 113,605 women were either serving a sentence in a local jail, state, or federal prison in 2012 (also see Sipes, 2012). Furthermore, The Sentencing Project (2012) provides that in 2011, there were 111,387 women confined in prisons and another 93,300 were located in the nation's jails. Glaze and Kaeble (2014) reported that between 2000 and 2010, the female population in jails and prisons had grown faster than male: the number of women jailed or imprisoned increased by 21 percent while the number of male prisoners increased by 15 percent.

Studies show that incarcerated women represent a growing segment of the prison population and present different issues for correctional staff and personnel since many of them (arguably 7 in 10) have children (Glaze \& Maruschak, 2010; Dallaire, 2007b; Richie, 2002). Research finds that female state inmates ages 25 to 34 (64 percent) were more likely to report being a parent, and sixty-two percent of overall female inmates in state prisons were mothers of minor children (Glaze \& Maruschak, 2010). Imprisoned mothers also spend a great deal of time thinking of re-establishing their family and role as a mother upon release. However, many of them fear that they or their children will not properly adjust when they reunite (Loper, Carlson, Levitt, \& Scheffel, 2009). 
The issue of women behind bars and their children may be greater than one might think. Statistics reveal that male state prisoners reported having a total of 1,559,200 children, while women state prisoners reported having a total of 147,400 children (Glaze \& Maruschak, 2010). It is reported that more than 1,300 children are born in prisons (Clarke \& Adashi, 2011; Amnesty International, 2000). Being confined presents many challenges and hardships to all parties concerned. Some of these range from experiencing grief to a lack of institutional adjustment, rule infraction to a lack of child development, attachment disruptions to academic difficulties, and even depression (Dallaire, 2007b; James \& Glaze, 2006). Under this circumstance, attention must focus on the negative impact that female incarceration has on children. The need is stronger in light of the facts that these children are innocent, and they lack secure attachment to their mothers which typically causes long-term negative effects.

This paper argues that infants and toddlers have a constitutionally protected right to have secure attachment with their long-term caregiver, namely their mothers. This is especially the case when their mothers are incarcerated by the government's action. These children have an affirmed right to have the government provide them with opportunities for achieving secure attachment with their long-term caregiver. Given that mothers are usually the primary long-term caregivers, prisons should provide opportunities in the form of prison nurseries. This paper will be divided into six parts. Part 2 discusses a brief history of nursery programs in the penal system. Part 3 presents the significance of early attachment to the maternal parent in general, and to incarcerated mothers in particular. Part 4 addresses (based on the findings in Part 3) the constitutional rights of infants and toddlers to have opportunities to form secure attachment to their mothers. Part 5 argues that if research proves effective, the infants and toddlers of incarcerated mothers have a right to prison nurseries as a constitutional right. In the final analysis, Part 6 presents viable policy implications.

\section{Prison Nurseries}

As previously stated, over sixty percent of incarcerated women in state prisons are mothers to minor children. It is believed that over half of the children to incarcerated mothers never see or have contact with their mothers until they are released (Morash \& Schram, 2002). The lack of contact is due to logistical and financial challenges, or the caregiver's unwillingness to expose children to prisons (Poehlmann, Shlafer, Maes, \& Hanneman, 2008). Because of incarceration, their children are often placed with relatives, the other parent, friends, or in state funded foster care systems (Glaze \& Maruschak, 2010). Needless to say, these mothers suffer as a consequence of not being able to care for their own children (see Poehlmann, 2005c). Most states require pregnant inmates to quickly place their infant with a family member or foster care after delivery (see Chambres, 2009). If the mother does not have a family, or some other support system, the child is placed in foster care. Once the child is placed in a state's foster care "for 15 of the most recent 22 months," the Federal Adoption and Safe Families Act requires "the State shall file a petition to terminate the parental rights of the child's parents..., and, concurrently, to ... approve a qualified family for an adoption" (42 U.S.C. $\S$ $675(5)(\mathrm{E}))$.

Innocent children are adversely impacted by maternal incarceration. Research have found children of incarcerated mothers often experience negative intellectual (Poehlmann, 2005b), psychological and/or behavioral (Murray \& Farrington, 2005; Myer, Smarsh, Amlund-Hagen, \& Kennon (1999) manifestations, and lower school performance (Cho, 2009). For example, children of incarcerated mothers face limited life chances, such as being three times more likely as adults to be convicted of a crime compared to their counterparts whose mothers were not confined (Huebner \& Gustafson, 2007). As discussed in detail below, research suggests that these impacts attributed, at least in part, to the lack of secure attachment relationship between children and their mothers as their long-term caregiver. Prison nurseries provide opportunities for children to achieve secure attachment to their incarcerated mothers. In addition, these opportunities allow mothers to nurse the infant and be responsible for the child and assist in their maternal development which could increase the likelihood that mothers will not recidivate and return to prison (Arditti \& Few, 2008; Villanueva, From, \& Lerner, 2009). In fact, one study revealed that the recidivism rates of women who participated in a prison nursery program in Nebraska was 16.8 percent, representing a 33.2 percent decline (Carlson, 2009; also see Carlson, 2001).

\subsection{History of Prison Nursery Programs}

The need for prison nurseries was recognized early in the nation's history. In fact, the first prison nursery opened at Bedford Hills Correctional Facility for Women (a maximum security) in New York in 1901. Mother-and-child programs were developed for incarcerated women dating as far back as the early 19th century (Craig, 2009). However, because historically, there have always been fewer women confined compared to men, confusion emerged regarding how women prisoners should be properly housed and managed. For example, in the 1800 s, several states enacted laws that permitted children to remain with their incarcerated mothers, but these laws were rarely enforced. A federal prison in Alderson, West Virginia, allowed children to stay with their incarcerated mothers from the 1930s through the 1960s until disturbing reports emerged regarding the negative effects that the prison environment had on children (Craig, 2009). According to 
Kauffman (2001), until the 1950s, nurseries were commonly found in state correctional facilities across the country. Consequently, efforts to allow nurseries in prison lost momentum by the 1960s, and by the early 1970s, only New York had not closed its nursery program. The other prisons closed their programs owing to costs and the lack of need since most newborns were placed with family members (Kauffman, 2001). However, the increase in the number of women arrested between 1986 and 2006 brought renewed interest, and a greater public awareness about the programs needed for inmate mothers, including nursery programs (Craig, 2009; see also Goshin \& Byrne, 2009; Glaze \& Maruschak, 2010).

\subsection{Prison Nurseries and Components}

Ten states are reported to currently (or plan to) provide nurseries to pregnant prisoners (Diamond, 2012; Villanueva, et al., 2009). These include California, New York, Nebraska, Washington, Ohio, Indiana, South Dakota, Illinois, West Virginia, and Wyoming. As of November 2015, Wyoming has not started the prison nursery program due to staffing issues (Hancock, 2015). Prison nursery programs provide a finite time period for infants to remain with their mothers after birth. The goals include promoting the mother-child bond and provide education to mothers (see Villanueva et al., 2009; Byrne, Goshin, \& Blanchard-Lewis, 2012; Carlson, 1998; Indiana Department of Correction, n.d.). Prison nursery programs are generally only open to mothers who give birth while incarcerated, and those who gave birth previously are not eligible for such programs (Villanueva et al, 2009).

Villanueva and colleges (2009) provide detailed descriptions of nine states which currently operates prison nursery programs. According to their research, the maximum length a baby can remain with the mother varies, with 30 days in South Dakota to 3 years in Washington. A majority of the states with prison nurseries permit them to stay together for twelve to eighteen months. Moreover, nursery programs are opened to mothers imprisoned for a low-level nonviolent crime, with a short sentence, and who will continue to be the primary caregiver after release; (Villanueva et al., 2009). Participating mothers must take child development and parenting classes (Villanueva et al., 2009). In Nebraska, women who participate in nursery programs must complete childcare and development classes, along with its GED program if they lack a diploma (Carlson, 2001).

\subsection{The Need for More Prison Nurseries}

Only 10 states offer nurseries to accommodate the needs of babies. In those states, prison nurseries are very limited. For example, Zou (2014) reports inmates' struggle to enter prison nursery programs in New York. According to DeBour (2012), the largest prison nursery (New York) has the capacity to hold 27 babies; In Illinois and Indiana, the numbers are 10 babies, respectively; In Nebraska, the number is 7; In Ohio, its facility can hold 21 babies; In Washington, its facility can hold 20 babies, and in West Virginia, it can hold 5 babies. It is alarming that only a few babies are provided with prison nurseries given data that suggest $61.7 \%$ of mothers in state prisons have minor children, and $18.3 \%$ of these mothers had children younger than 4 (Glaze \& Maruschak, 2010). Moreover, four percent of women in state prisons, and three percent in federal prisons, were reportedly pregnant at the time of their admission (Maruschak, 2008). Notwithstanding, five percent of female jail inmates self-report being pregnant at the time of admission (Maruschak, 2006) and the fact that more than 1,300 babies are born in prisons each year. Part 3 will show that infants and toddlers who achieve secure attachment with their mothers grow to be more self-reliant, have higher self-esteem as young children which gives them the ability later in life to have successful peer relationships and cope better with stress. Because of the critical importance of secure attachment, the effectiveness of existing nursery programs (discussed later in Part 4), these programs should be readily available to suitable mothers and their infants and toddlers.

\section{Significance of Secure Attachment to Incarcerated Mothers}

\subsection{Critical Importance of Secure Attachment with Caregivers}

Scholars have argued that it is of the utmost importance that infants and toddlers have a secure attachment to their caregiver. Attachment is evolutionary and biological and is based on behavioral systems that help infants survive during early childhood (Bowlby, 1969). In other words, if children are attached to a protector, their rate of survival increases (Bowlby, 1969; Ainsworth \& Bell, 1970). In recent years, emphasis has been placed on early attachment research, and its impact on children's personality, development, and health (Bowlby, 1969; Ainsworth, 1989). Various scholars including John Bowlby and Mary Ainsworth contributed to research on the significance of early attachment. Ainsworth categorized children's attachment to their parents as either secure, ambivalent insecure, and avoidant insecure (see Ainsworth, 1979; also see Ainsworth \& Bell, 1969). The differences in attachment arise from early experiences in recurring interactions with attachment figures. For example, infant attachment could manifest when a mother playing with her infant leaves the room and separates from the infant. The infant is then placed in an unfamiliar situation (e.g., "strange situation"). During this brief separation, infants typically display distress. The infant's attachment style appears when the mother returns and reunites with the infant. Upon the mother's return, a securely attached child seeks proximity and comfort from the mother, and if the infant is still upset, he or she eventually calms down. An infant with insecure-avoidant attachment does not seek proximity to the mother after her return, or display distress to the mother 
(insecure/avoidant attachment). A child with insecure-ambivalent (or anxious) attachment strongly demonstrates distress during the mother's absence, and upon her return, the infant does not calm down for prolonged periods of time (see Ainsworth, 1979; van Rosmalen, van Ijzendoorn, \& Bakermans-Kranenburg, 2014). To Ainsworth's attachment categories, Main and Solomon (1986) added two categories entitled: disorganized and disoriented. Some studies indicate that insecure attachment patterns are manifestations of children's defensive, adaptive mechanism, or attempts to cope with the rejection or unresponsiveness of their mothers (Cassidy, 2001; Weinfield, Sroufe, Egeland, \& Carlson, 2008).

The attachment style that children develop is determined by the caregiver's attention and ability to sensitively understand the feelings of the child and respond to his or her needs. In traditional family structures, primary caregivers are either one or both parents who serve as the primary attachment figure. The quality of responsiveness from primary caregivers results in the development of comfort with interpersonal closeness and willingness to depend on others. This allows infants to develop secure attachments. Thus, it is the caregiver's sensitive response to the needs of infants that helps facilitate secure attachment. The availability of an attachment figure is critical in order to from secure attachment (Murray \& Murray, 2010; Shlafer \& Poehlmann, 2010). The early separation of the mother and infant causes severe disruption in the attachment relationship (Dallaire, 2007b). Bowlby (1969, citing Ainsworth, 1963; 1967) found that infant attachment starts as early as six to nine months. Thus, it is the beginning of an important period of attachment for the infant-child.

Research supports Bowlby's claims of the importance of early attachment between mother and child, when it revealed young children's attachment style is highly likely to continue throughout adulthood (Waters, Hamilton, \& Weinf, 2000; Fonagy, Target, \& Gergely, 2000; Fonagy, Lorenzini, Campbell, \& Luyten, 2014). A study revealed that there was a relationship (68-75\%) between attachment styles in childhood and adulthood (Fonagy et al., 2000). Therefore, early attachment style can serve as a blueprint of the child's future behaviors such as caregiving, resilience, friendships, exploration, and others (Mikulincer \& Shaver, 2007). From infancy, children internalize and organize patterns and expectations relating to people, and reactions to stressful situations that provide insight into many other human behaviors (Ainsworth, 1989; Bowlby, 1988; Siegel, 2002). While securely attached individuals display competence and trustworthiness, they are also able to relate and trust others, display independence, feel confident, explore freely, and learn cognitive skills and tasks that increase their chances of success.

Scholars pointed out the vital need of infants to acquire secure attachment in order to have a healthy future. For example, secure attachment is a fundamental basis of "personal growth and self-actualization" (Mikulincer \& Shaver, 2007, p. 142). To the point, Cassidy (2001) argues that infants' secure attachment facilitates the ability required to achieve intimacy later in life. He argues that intimacy is a critical factor for both physical and mental health. In contrast, insecure attachment styles develop in response to inconsistent or unresponsive caregiving and is linked to being anxious, feeling rejected, having discomfort with relationships, low self-esteem, poor psychological adjustment, and having poor health, along with other behavioral limitations.

Insecure attachment during childhood not only hinders healthy development, but can also lead to physical ailments and mental and personality disorders. For example, in a longitudinal study, Puig and colleagues (2013) examined the attachment style of subjects at the ages of 12 and 18 months and their physical health 30 years later. They found the attachment style of the subjects was developed at infancy and served as a predictor of future physical ailments. According to the study, one possible explanation for this nexus is that long-term exposure to stressors resulted in weaker regulation of inflammatory response, resulting in an excessive amount of inflammation. In the long run, this resulted in cardiovascular disease and metabolic syndrome. In contrast, the study also showed that subjects who were securely attached at ages 12 and 18 months had fewer health problems as adults. In another study, Anderson and Whitaker (2011) found a relationship between insecure attachment style (formed during childhood) and obesity. They reported that children at the age of 24 months, with insecure attachments had a higher risk of obesity at age 4.5 years. The study suggested that this was probably due to poor dietary habits that may have been used to help them cope with stress. Similarly, Anderson and colleagues (2012) found that the association of insecure attachment and adolescent obesity manifests by age 15 .

Some studies have suggested that children's insecure attachment can be linked to negative psychological or antisocial disorders as they approach adulthood (Siegel, 2012). For example, research finds a link between insecure attachment in childhood and the risk of general anxiety disorders (Cassidy, Lichtenstein-Phelps, Sibrava, Thomas, \& Borkovec, 2009; Nolte, Guiney, Fonagy, Mayes, \& Luyten, 2011; Mineka, Watson, \& Clark, 1998) and depression (Lee \& Hankin, 2009) later in life. Other research finds that insecure attachment is a factor in borderline personality disorders (Fonagy et al., 2000; Fonagy, Target, Gergely, Allen, \& Bateman, 2003; Bakermans-Kranenburg \& van Ijzendoorn, 2009; Carlson, Egeland, \& Sroufe, 2009; Fonagy et al., 2014). Again, these studies tends to show how important it is to a child's future that he or she develops a healthy attachment at an early age, especially, between six months and the 
second year, since it will invariably affect the rest of their lives.

\subsection{Attachment Style of Children with Incarcerated Mothers}

Research suggests that the children of incarcerated mothers tend to have an insecure attachment at a disproportionate rate. In fact, Poehlmann (2005a) reported that $63 \%$ of children (2.5-7 years) to incarcerated mothers between the ages of 2.5 to seven displayed insecure attachment. Insecure attachment can be caused by separation between parent and child due to incarceration, but it can also be rooted in traumatic events such as parental arrest, uncertainty during pretrial, or the trial stages of the criminal justice process (Murray \& Murray, 2010).

Some research suggests an intergenerational nature of delinquent and criminal behaviors that result in incarceration (Greene, Haney, \& Hurtado, 2000; Arditti, 2012; Murray \& Farrington, 2005; Huebner \& Gustafson, 2007; Dallaire 2007a). Criminologists find the lack of connection between parents and children can be a causal factor of delinquency. For example, Hirschi (1969) explained that attachment is the primary bond through which children internalize conventional norms of society. Consequently, he argued that if children have strong or secure bonds, and a good relationship with parents, it can protect them from delinquency and crime. Likewise, other research shows that children reared without both parents face a higher risk of engaging in delinquency and crime than their counterparts who have both parents in the home (Kierkus \& Baer, 2002). Murray and Farrington (2005) report that when the separation between parent and child is owing to parental incarceration, delinquency and crime are more likely to occur than when the separation is caused by other reasons.

Despite the benefits of being nurtured by a grandparent, older sibling, or foster parent, these substitutes are equal to the quality of bonding and attachment found in a long-term mother and infant-child relationship. While children can have an attachment to their fathers, their availability as a stable long-term caregiver is often limited. When the mother is incarcerated, or gives birth in prison, the child is more often placed in the care of his or her grandparent (44.9\%), other relatives (22.8\%), foster care (10.9\%), and friends/others (7.8\%) (Glaze \& Maruschak, 2010). Compared to children of incarcerated fathers, children of incarcerated mothers are more likely to be placed in nonfamilial care (Glaze \& Maruschak, 2010; Dallaire, 2007a). This may suggest that when mothers face incarceration, the father is also incarcerated, not always present or willing to assume the responsibility of child rearing. Therefore, children with incarcerated mothers become uprooted from their homes, sometimes frequently in a given year. The instability or disruption of home life can compound the already detrimental risk factors for children born to incarcerated mothers (Dallaire, 2007a; Greene et al, 2000). According to Miller (2006), some adverse consequences faced by children with an incarcerated parent include cognitive delays, developmental regression, or develop inappropriate coping strategies. Children in these situations are at a greater risk of facing psychological problems as well as engaging in delinquency and crime (Shannon \& Abrams, 2007).

\section{The US Constitution and the Rights of Infants and Toddlers}

\subsection{Constitutional Rights to Have Opportunities to Form Secure Attachment}

Because of the critical importance of having secure attachment in early life, this paper argues that infants and toddlers have a constitutional right to have opportunities to form secure attachment with their willing mothers. This right can be considered part of the infants and toddlers' right to be provided with the necessities for healthy growth and development. This right would be violated if, for example, the government banned caregivers from providing such necessities to children. Because of the importance of achieving secure attachment, we view opportunities to attain it as a fundamental necessity owed to persons in the very early stage of their life. As such, we claim that this right is protected by the US Constitution.

Despite the similarities to having food and other necessities, there are at least two stark differences that make the right to have opportunities to form secure attachment unique. Unlike food, or safety that can be provided by any caregiver who may not be the mother, attachment needs to be formed with a child's long-term caregiver, which is usually the mother. Thus, this paper contend that infants have a right to have the opportunity to form a secure attachment with their mothers, the most common primary caregiver, as long as she is willing and capable.

4.2 The Due Process Clause and the Right to Opportunities to Form Secure Attachment to their Long-term Caregiver Secure attachment to a primary caregiver (typically a mother) is just as important to early development as other necessities such as proper nutrition, safety and care. If the primary caregiver is the mother, which is often the case, children should have a right to pursue secure attachment with her under the US Constitution. This right may prohibit the government from denying infants and toddlers the opportunity to form attachments during critical periods of their growth and development.

Infants' and children's right to secure attachment with their mothers can be recognized under the Due Process Clauses in the US Constitution in the Fifth (applicable to the federal government) and Fourteenth (applicable to the States) 
Amendments. While these provisions certainly do not explicitly contain this right, the issue (and right) would be as important as other rights the US Supreme Court has protected under these provisions. To the point, the Supreme Court has recognized that individuals' personal autonomous choices and bodily integrity are protected liberties under these Clauses. These liberties include: the right to procreate (or not to) (e.g., Carey v. Population Service International, 1977; Roe v. Wade, 1973, Planned Parenthood v. Casey, 1992; cf. Griswold v. Connecticut, 1965), intimate heterosexual or same-sex relationship and marriage (e.g., Loving v. Virginia, 1967; Lawrence v. Texas, 2003; Turner v. Safley, 1987; Obergefell v. Hodges, 2015), child rearing and family autonomy (Meyer v. Nebraska, 1923; Pierce v. Society of Sisters, 1925; Wisconsin v. Yoder, 1972; Moore v. East Cleveland, 1977), freedom from physical restraint, or violence (Youngberg v. Romeo, 1982; Parham v. J.R., 1972) and the right to refuse medical treatment (Cruzan v. Director of Missouri Department of Health, 1990; Washington v. Harper, 1990; Sell v. United States, 2003; Riggins v. Nevada, 1992). The Supreme Court has granted constitutional protection of these liberties based on their value of personal autonomy, dignity and personhood, and/or the value of bodily integrity. Along with these liberties, infants and toddlers have a right to have opportunities to form secure attachment with their caregivers, because of their values in bodily integrity, and personal autonomy. The subsequent sections discuss the bodily integrity and personal autonomy.

\subsection{Bodily and Mental Integrity}

The Supreme Court has held that freedom from physical constraints, corporal punishment, and unwanted medical intervention are matters of bodily security and or integrity (e.g., Ingraham v. Wright, 1977; Youngberg v. Romeo, 1982; Washington v. Harper, 1990; Sell v. United States, 2003; Cruzan v. Director, Missouri Department of Health, 1990). For example, the Supreme Court in Harper stated, "[t]he forcible injection of medication into a nonconsenting person's body represents a substantial interference with that person's liberty" (Washington v. Harper, p. 229). The Court also ruled that women's reproductive decisions are a matter of bodily integrity, as well as autonomy (Planned Parenthood $v$. Casey, 1992). As such, children's rights to seek secure attachment could be considered a matter of bodily integrity, and also personal autonomy. More specifically, research discussed earlier, evidenced a strong link between insecure attachment and resulting physical illness, such as inflammatory disease, obesity, and even delinquency. Furthermore, the unhealthy relationships children will develop because of a lack of secure attachment in the early stage of life may later manifest into physical illness. Notwithstanding this compelling reason, additional research is needed in two points: First, more evidence is needed to link insecure attachment with other physical illnesses, and psychological/behavioral disorders. Second, more evidence is also needed that shows maternal incarceration leads to insecure attachment. However, if these causal links are established, courts can ponder whether the government either caused or contributed to illnesses found among these infants and children. Thus, depriving mothers and violating these infants' and children's constitutional right of bodily integrity.

The right of bodily integrity is not limited to freedom from physical invasion or illness, but also includes what Shapiro (2002) refers to as "mental integrity" (p. 440). Henkin (1992) explains that "human dignity requires respect for every individual's physical and psychic integrity" (pp. 210-211). If maternal incarceration causes insecure attachment that leads to personality disorders among their children, this can be viewed as a violation of bodily integrity (mental integrity). As discussed earlier, research has found that insecure attachment may cause serious psychological or behavioral disorders. Moreover, all persons, regardless of age or mental capacity, have the right to bodily integrity. While exercising some constitutional rights need certain capacity (e.g., freedom of expression or the right to marry), other constitutional rights confer protection to individuals because of them being a person, generally regardless of the person's age or capacity. These rights include the right to life, and freedom from racial, gender, or other discrimination. In the same way, infants' right to basic necessities and the right to have opportunities to form secure attachment with their mothers should not depend on their decisionmaking capacity.

It should also be noted that the rights of children discussed here are not the rights to guaranteed secure attachment. Even under responsive care, children may not achieve secure attachment. Other factors beyond the control of the caregiver or government can also affect the chance of secure attachment. Nevertheless, research shows that the environment and caregiver's attitude are important factors that influence secure attachment. Moreover, while the government does not need to guarantee that each child attains secure attachment, it should not deprive infants and toddlers of any opportunities to form secure attachment. Some argue that incarceration deprives mother-child interactions and bonding. Similarly, a government should not deprive children of an opportunity to receive healthy growth and development by prohibiting them from receiving proper nutrition or an education, even though healthy nutrition or a proper education will not guarantee healthy growth and development.

\subsection{Personal Autonomy and Dignity}

If the government denies children the opportunity to acquire secure attachment with their mothers, this could also constitute an invasion of the children's autonomy, personhood, and dignity. Insecure attachment can affect children's 
physical and mental health, and their future decision making or autonomy regarding matters essential to their personhood and dignity. The Supreme Court has recognized that "choices central to personal dignity and autonomy" (Planned Parenthood v. Casey, 1992) are protected by the Due Process Clause. These matters have included issues related to procreation, family, marriage and other intimate relationships (e.g., Moore v. East Cleveland, 1977; Loving v. Virginia, 1967; Obergefell v. Hodges, 2015; Lawrence v. Texas, 2003; Carey v. Population Service International, 1977; Roe v. Wade, 1973; Griswold v. Connecticut, 1965), child rearing, and education (Meyer v. Nebraska, 1923; Pierce v. Society of Sisters, 1925; Wisconsin v. Yoder, 1972).

While it is true that infants do not have the capacity to exercise their autonomy, the constitutional protection of autonomy arguably extends to having autonomy in the future. A government-induced insecure attachment can be viewed as an invasion of children's autonomy since it deprives their future decision-making ability, which results in the denial of personhood, and dignity of the person. As discussed above, research literature indicated that insecure childhood attachment can lead to mental disorders. These conditions can severely impair children's ability to make important autonomous choices throughout their life-course. Therefore, personality disorders can substantially affect their ability to enter into and maintain healthy relationships. Furthermore, antisocial and delinquent behavior caused by the lack of having secure attachment may result in delinquency, violence, adult offending, and later incarceration, which can substantially limit life choices essential to one's dignity and personhood. Consequently, the government infringes on the personhood of children by preventing them from forming secure attachment with incarcerated mothers, a violation of their personal autonomy which limits their ability to exercise autonomy in the future. Similarly, Dailey (2011) advocates recognizing constitutional "'developmental rights' that operate to secure children's future autonomy by promoting their socialization into autonomous adults" (p. 2103). She argues that any matter that is essential to children's growth to becoming autonomous persons should be protected under the Constitution. More specifically, Dailey advanced constitutional protections of the caregiver-child relationship, but did not discuss the constitutional protection of children's secure attachment opportunities with their incarcerated mothers. However, this right can be recognized as a constitutional right under the theory since secure attachment is essential to children's ability to develop the skills necessary to make autonomous decisions. Taken to its logical conclusion, a governmental deprivation of providing infants and toddlers' opportunities to form secure attachment is equivalent to depriving children of essentials such as proper nutrition, safety, and education, the lack of which may result in long-term negative effects. As such, secure attachment, or at least, an opportunity to acquire it, is among children's basic sustenance. According to Chemerinsky (1993) basic sustenance is "the prerequisite for the exercise of all rights" (p. 539).

\subsection{The Right to Intimate Association}

The government's denial of opportunities to infants to form secure attachment with their mothers violates personal autonomy and dignity in another way. This occurs when the government deprives children of the right to be with their willing and capable mothers. Some personal autonomy issues that the US Supreme Court have recognized include: decisions about the family and other close relationships, such as marriage, living with grandchildren, and non-marital sexual relationships, and being a parent. Attachment is more than mere personal connection; it is also an essential aspect of intimate association. However, the Supreme Court is reluctant to consider children's right to intimate association with an adult independently of the adult's right to intimate association with the child. In other words, when the relationship between a child and an adult (caregiver/parent of the child) is at issue, courts tend to consider whether the adult has a right to the child, and do not independently consider whether the child has a right to the adult.

In Overton v. Bazzetta (2002), inmates and family members who were denied contact visits in prison claimed the policy violated parents' as well as their children's right to intimate association. In this case, the US Supreme Court did not consider the children's right to intimate association independently of the inmate's rights to association with the family member. The Court suggested that a parent's status as a convicted inmate weaken the right to intimate association of both the inmate and their children. Thus, the prison regulation that denied visitation to certain inmates was held as constitutional unless it was deemed unreasonable. However, the decision posed several problems. First, it failed to properly consider the innocence of visiting children. After all, children are not convicted offenders, and thus, their right to parents is not any weaker than those whose parents are not incarcerated. Second, and perhaps more importantly, their status as children of an incarcerated parent allows no room for the children's choice, unlike other intimate relationships such as marriage. As for marriage between inmate and noninmates, the Supreme Court ruled that such marriages are protected under the Constitution and cannot be banned, but these marriages are subject to reasonable prison regulations (Turner v. Safley, 1987). This restriction is understandable since marriage is a choice. Also, the parent-children relationship differs from the adult sibling relationship. While a blood sibling relationship is not a choice for siblings, the degree of intimacy between adult siblings is a choice. In contrast, the relationship between a parent and a child, especially infants and toddlers, is not the child's choice. For infants and toddlers, bonding with their parent is not a matter of choice, but rather a necessity. Moreover, the courts' general failure to recognize children's right to intimate 
relationship independently from the parent's right to intimate relationship has been criticized by legal scholars, especially in the context of child custody law. These scholars has urged courts to consider the adult's right to child rearing, and also respect for children's constitutional right to have intimate association with the caregiver that serves their best interests (e.g., Byrn \& Ives, 2010; Dailey, 2011; Kindred, 1996; McLaughlin, 2009; Holmes, 1994).

\subsection{Negative Rights vs Affirmative/Positive Rights}

This paper has discussed negative, rather than, affirmative rights. Negative liberties are rights to be free from governmental intrusion. Affirmative rights are those that require the government to act or provide. For example, the right to an attorney has both aspects: the choice to retain the right without governmental intervention (negative liberty); while an indigent defendant has a right to have a government appointed attorney (affirmative right). It is the position of the US Supreme Court that with a few exceptions, the rights the Constitution provides are negative liberties (e.g., DeShaney v. Winnebago County Department of Social Services, 1989). For example, freedom of speech does not require the government to provide the means to expression. Likewise, the right to marry does not require the government to provide a worthy potential spouse. Accordingly, the claim to have the constitutional rights to have the government provide: welfare, housing, or education have been denied by the Supreme Court (e.g., Dandridge v. Williams, 1970; James v. Valtierra, 1971; San Antonio Independent School District v. Rodriguez, 1973). Legal scholars often criticize the Supreme Court's position on these issues and have argued for the government's constitutional duty to provide welfare, health care, or school funding (Chemerinsky, 1993; Dailey, 2011; Ezer, 2004). It is not the focus of this paper to analyze whether all infants and toddlers should receive opportunities to form secure attachment as an affirmative right. That is, the right to require the government to provide opportunities to form secure attachment. Regardless, the Supreme Court's general denial of affirmative rights has widely recognized exceptions. The most relevant is that the "state-created danger" exception. By incarcerating the mother, the government creates a danger since it deprives the child of a vital need to form a secure attachment to his or her mother. Because of this "creation of danger," the government now has an affirmative duty to provide opportunities for the child to acquire secure attachment to an incarcerated mother. Part 5 addresses this constitutional duty.

\section{Prison Nurseries as a Constitutional Requirement}

If infants are afforded the right to have opportunities to form secure attachments with their mothers, the government should provide such opportunities, especially when it places children at risk by incarcerating their mothers. Most incarcerated mothers are single parents with children who lack a father as their primary caregiver. In most cases, family members or foster care may not be viewed as a suitable care provider, and many incarcerated mothers will be released and returned to their children as the primary caregiver. While the research is limited, it suggests that children who stayed in prison nurseries can at least have the same, if not a better chance of securing an attachment to their mothers. Given this finding, and the importance of secure attachment, the government must provide children with the opportunity to form attachment to their mothers, especially when they are capable and willing to accept this responsibility and when children do not have a suitable long-term caregiver, such as their fathers.

\subsection{Critical Benefits of Prison Nursery Programs}

The physical separation of the infant and mother after birth severely impacts the development of the mother-child bond and can be viewed as traumatic for both parties (Arditti \& Few, 2008; Imber-Black, 2008). This bond is important to mothers who desire to care for their children after they have completed their sentence of incarceration (Makariev \& Shaver, 2010). Some scholars argue that by not separating the mother and child, a prison nursery can provide them with an opportunity to bond since mothers will be allowed to hold, breastfeed, change diapers, protect, and provide caregiving duties to the child (Huang, Atlas, \& Parvez, 2012).

\subsection{Benefits to Infants and Toddlers}

Several programs have been created to mediate the psychological effects of maternal incarceration. Positive attachment relationships between the parent (and the child's caregiver while they are in prison) are among the most protective factors in a child's life (Luke, 2002). These programs foster positive attachments between parents and their children. As a result, they contribute to improved behavior, better academic performances, and increased self-esteem among the children of incarcerated parents (Block \& Potthast, 1998; Dunn \& Arbuckle, 2002 as cited in Miller, 2006). Moreover, research by Byrne and colleagues (2010) indicate that the secure attachment rate of babies in prison nursery is as high as those reared in low-risk communities/families, especially when the baby lives with the mother for more than one year (Byrne, Goshin, \& Joestl, 2010). According to the study, if newborn infants live with the mother for more than one year, $60 \%$ acquire secure attachment. They also report that when infants stay less than a year, $43 \%$ acquire secure attachment. The research further shows that the rate of secure attachment is high, even when the mother failed to secure attachment with her own parents (Byrne et al., 2010). This is surprising since some research suggests that children are less likely to acquire secure attachment when their mother did not attain it as a child. In essence, the consensus is that 
insecure attachment is intergenerational, in that, if the mother was reared with insecure attachment, she is less likely to effectively and sensitively understand the needs and feelings of others, including her own children (Byne et al., 2010; van IJzendoorn, Juffer, \& Duyvesteyn, 1995). Thus, research supports that using prison nurseries may prevent the cycle of intergenerational insecure attachments from persisting.

Studies also reveal that living in a prison nursery can have a positive effect on children. For example, reports by Goshin, Byrne, and Blanchard-Lewis (2014) revealed preschool toddlers who lived in a prison nursery for longer than one year developed more resilience to anxious and depressed behavioral issues than others in high-risk living environments. This suggests that infants who lived with an incarcerated mother developed a secure attachment that served as a protective buffer against anxiety and depressive behavioral influences while living in a high risk environment (Goshin et al., 2014). This finding is particularly important because in most cases, many incarcerated mothers and their children will return to a high-risk environment following post-conviction release. This finding strongly suggests that children's secure attachment with their mothers can be acquired as they live with them in prison nurseries.

A prison nursery provides infants and mothers with a relatively safe environment that has secure resources and delayed exposure to other environmental risk factors (Borelli, Goshin, Joestl, Clark, \& Byrne, 2010). Haung, Atlas, and Parvez (2012) provide that these environments enable pregnant women or postpartum mothers (who are at an increased risk), the opportunity to receive healthcare for their infants and themselves as well as educational assistance to properly care for their children. Incarceration also provides mothers an opportunity to address their personal problems, and acquire effective parenting skills (Makariev \& Shaver, 2010). Moreover, the benefits of breastfeeding extend beyond nutritional intake for children, but it helps the mother and infant to bond. Scholars report that breastfeeding brings healthy developmental and immunological benefits to infants that manifest later. It also has psychological benefits for the mother and infant since breastfeeding is linked to a mother's positive self-image, secure attachment formation, and competent children (Allen \& Baker, 2013).

\subsection{Benefits to Incarcerated Mothers}

While this paper primarily focused on children's constitutional rights to the opportunities to develop secure attachment with their incarcerated mothers, it is worth mentioning that prison nurseries provide substantial benefits to incarcerated mothers. Research suggests that prison parenting programs have been effective in helping to reduce recidivism rates, improve mothers' social skills and negative behavior, and improve the quality of mental health among incarcerated mothers (Arditti \& Few, 2008; Carlson, 2009, 2001; Sandifer, 2008). Research also demonstrated that programs that foster attachment improved the parent's perceived relationship with their child, and helped repair bonds that were broken during their incarceration (Engstrom, 2008; Luke, 2002; Miller, 2006; Poehlmann, 2005a).

Some studies report that these mothers experience guilt and other negative emotions that include mental health problems (Arditti \& Few, 2008; Imber-Black, 2008). At the same time, despite the negative consequences incarcerated mothers face, many consider motherhood an impetus for surviving their confinement (Shamai \& Kochal, 2008). In fact, some incarcerated mothers consider motherhood as their primary reason for enduring the negative experience of incarceration that could affect them and their relationship with their children (Shamai \& Kochal, 2008).

\subsection{Infants and Toddlers' Affirmative Constitutional Right to Prison Nurseries}

A prison nursery is critical to the health and developmental needs of infants and children while their mothers are incarcerated. At the same time, the constitutional right to have opportunities to form secure attachment is primarily framed as a negative right, freedom from governmental intervention or intrusion. Such a right prevents the government from intervening with opportunities where infants and toddlers can form secure attachment with their mothers (but does not generally impose an affirmative duty on the government to provide such an opportunity). If this is the case, how can we claim a constitutional right that the government should provide prison nurseries? We consider this plausible. Despite legal scholars' claims that the Constitution should impose an affirmative duty on the government to provide basic sustenance (Michelman, 1969; Chemerinsky, 1993; Kindred, 1996; Ezer, 2004; Dailey, 2011), the Supreme Court has considered these constitutional rights as generally negative rights (DeShaney v. Winnebago County Department of Social Services, 1989). However, the Court recognized these rights can become affirmative rights under limited exceptions (e.g., DeShaney, 1989; Castle Rock v. Gonzales, 2005). First, when there is a special relationship that exists between the government and the individual. For example, prisoners have a constitutional right to humane prison conditions, which imposes an affirmative duty on the government to provide adequate nutrition, medical care, and safety (e.g., Estelle v. Gamble, 1976; Farmer v. Brennan, 1994; Brown v. Plata, 2011). Similarly, under the Constitution, the government has an affirmative duty to provide involuntarily institutionalized patients with safety (Youngberg v. Romeo, 1982; see Jackson \& Fasiq, 2011). The government owes an affirmative duty to provide the necessities to those in its custody. This includes infants born in prisons to incarcerated mothers. With that said, the 
government's duty to provide a nursery for infants and toddlers of incarcerated mothers, including those not born in prison, can be better explained by using the second exception.

Under the second exception, the government owes an affirmative constitutional duty of care when it creates a risk of harming a person's constitutionally-protected interests (DeShaney, 1989; Bowers v. DeVito, 1982). While considering the critical importance of infants' and toddlers' opportunity to form secure attachment to a long-term caregiver, if the government deprives them of physical access to their mothers, it jeopardizes the right to form secure attachment and infringes its affirmative duty to provide such an opportunity. Moreover, when it is established that prison nurseries are the opportunity for infants and children to form secure attachment, the government has a duty to provide them.

The fact that the mother's incarceration is a product of her own criminal conduct is not relevant to the government's duty towards innocent children. In fact, the government's removal of the mother from the child, essentially deprives them of the right to form secure attachment, and while confinement may be justified, it is still a deliberate act by the government. This does not change even though the offender may have deliberately violated the criminal law. Under the US Constitution, the government has broad discretion regarding what should be a crime and how it should be punished. The Constitution does not require prosecution or incarceration of particular individuals. These choices are made by the government. As such, when the government decides to incarcerate a mother, it also knowingly places the infant or toddlers in danger, in the way these children are often deprived of the primary caregiver who typically provides basic sustenance and care, such as nutrition, accommodation, and the opportunity to form secure attachment. Because the government's choice to incarcerate the mother infringes on children's rights to basic sustenance and care, including the opportunity to form attachment, it is the government's affirmative duty to provide it, and a failure to do so constitutes a constitutional violation.

\subsection{Need of Prison Nurseries and Some Viable Alternatives}

This article has discussed infants and toddlers' constitutional rights to form a secure attachment to their primary caregiver, namely a mother. We have focused on those children's attachment to their mothers because incarcerated mothers are most often the sole caregiver of children after release. Thus, we argue that if current medical and social scientific research is correct, it is essential that children are afforded opportunities to form secure attachment with their mothers. We also cited several Court cases that we believe evidence that the US Constitution will require the government to provide prison nurseries. However, this does not suggest that children's secure attachment should always be extended to every mother. At least under the following circumstances, the government should be allowed to use other methods to protect children's opportunity to form secure attachment to a long-term caregiver. First, the mother may be deemed unfit to be a long-term caregiver. This could be because she is unwilling to rear children. A secure attachment cannot occur in a prison nursery without a mother's desire to participate and devote herself to becoming a long-term care provider. Second, a prison mother may be serving a long sentence without the possibility of being released in the near future. Similarly, a mother may have a serious medical or personality issue, or a history of substance abuse that cannot be treated or overcome. If so, the opportunity to form an attachment should be given to someone else. Third, even in cases where a mother is qualified and has a release date in the near future, the child's father may be a suitable long-term caregiver. Under this circumstance, the child's attachment to the father should be considered, and the child's right to form secure attachment can be acquired without placing him or her in a prison nursery. However, the reality of these situations is that the male counterparts to incarcerated mothers are not often long term caregivers.

While prison nurseries are currently exclusively for babies born to incarcerated mothers, they should not be limited to children born in prisons. We see little or no constitutional distinction between them and babies born before the mothers' incarceration. The importance of secure attachment and the right to attachment opportunities are not limited to children born in prison. Nor does the government's constitutional duty to provide such opportunities depend on whether they were born before or after the mother's incarceration, but rather, it is derived from the fact that the government deprived the mothers of this right by incarcerating her. Thus, these nurseries should be available to infants and toddlers born before incarceration.

When children lack an alternative stable long-term primary caregiver, the government can impose a number of options that go beyond the use of prison nurseries. These options can allow punishing the mother for her crime without disadvantaging infants and children who benefit from having access to her to form a secure attachment. For example, scholars suggest that depending on the gravity of the criminality committed, some mothers can receive a community-based sentence, rather than being remanded to institutional custody and separated from her children (see Jbara, 2012; Gilad, 2013; McMillen, 2012) or that judges should be allowed to consider parenthood as a mitigating factor in determining an appropriate sentence for pregnant offenders as well as women offenders who have young children (Boudin, 2011). Under community-based corrections, a mother can serve a sentence of probation that allows 
her to continue interacting and bonding with her infant or children. She could also be sentenced to a home-based program, such as JusticeHome, a program used in New York for mothers who faced a minimum of six months of incarceration, but plead guilty to felony charges. The program allowed mothers to remain at home bonding with their children under the supervision of a case worker who makes routine visits and provides needed services. Upon completion of the program, charges are dismissed (Berger, 2013). In other cases, the government can explore options such as residential programs designed so that offenders and their children can live together in a supervised facility. Such programs are needed since they are aimed at preventing children of incarcerated mothers from developing avoidant or insecure attachments. Experts believe that by increasing the level of awareness of the needs faced by incarcerated mothers and their children, a significant number of infants and toddlers can achieve "secure" attachment (Cassidy et al., 2010).

\section{Policy Implications}

This article has discussed infants and toddlers' constitutional rights to form a secure attachment to their primary caregiver, namely a mother. Throughout this investigation, research has revealed the critical importance of children securing an attachment in the early stages of life. The need to secure an attachment is comparable to other basic needs that children have such as nutrition, safety, and care. The right to have access to these needs is fundamental to children's bodily integrity and their future exercise of autonomy. Therefore, this right deserves protection under the due process clause of the US Constitution. While the right of infants and toddlers' to have opportunities to form a secure attachment is generally viewed as a negative right, the right to be free from governmental intervention becomes an affirmative right in limited situations such as when the government deprives caregivers of their children and place them at risk. Thus, infants and toddlers whose parents are incarcerated have an affirmative right to have the government provide opportunities for them to form secure attachment to their mothers as long-term caregivers. Moreover, research continues to demonstrate that prison nurseries provide effective opportunities for children to form secure attachment. Thus, this paper has argued that since research shows that prison nursery are effective in helping infants and toddlers form secure attachment to their mothers, courts should recognize the government's constitutional duty to provide more of these programs.

Certainly not every pregnant inmate will qualify for participation in prison nursery programs. In some instances, the government should implement alternative methods to protect children's opportunities to form a secure attachment to a long-term caregiver. First, when the mother is determined as unfit to be a long-term caregiver, perhaps because she is unwilling to rear children. Consequently, a secure attachment cannot develop in a prison nursery without a mother's desire to fully participate and devote herself to becoming a long-term care provider. Second, when the mother receives a long term sentence without the possibility of being released in the near future, this is similar to a mother with serious medical or personality issues, or a history of substance abuse that cannot be treated or overcome. If so, the opportunity to form an attachment should be given to someone else. Third, even in cases where a mother is qualified and has a release date in the near future, the child's father may be a more suitable long-term caregiver. In this case, the child's attachment to the father should be considered, and the child's right to form a secure attachment can be acquired without placing him or her in a prison nursery. However, as discussed above, the reality is that in many cases, male counterparts to incarcerated mothers are not long term caregivers.

While prison nurseries are exclusively for babies born to incarcerated mothers, they should not be limited to children born in prisons. We see little or no constitutionally significant reasons to distinguish between them and babies born before the mothers' incarceration. From the child's perspective, there is the deprivation of the mother. The importance of forming a secure attachment and having the right to attachment opportunities are not limited to children born in prison. Nor does the government's constitutional duty to provide such opportunities depend on whether children were born before or after the mother's incarceration, but rather, it is derived from the fact that the government deprived mothers of this right by incarcerating them. Thus, nurseries should be available to infants and toddlers born before incarceration.

As mentioned earlier, the few prison nurseries that exist are effective at reducing recidivism among women who participate in them. Those who participate are also more likely to adjust to their incarceration, in that, they are more inclined to follow prison regulations and commit less rule infraction compared to other incarcerated women who do not participate in these programs. However, and most importantly, infants and toddlers are healthier when they are kept with their mothers and are not taken through forced separation quickly after birth. Because they are allowed to develop secure attachment through bonding with their mothers, they experience healthy development in their physical, mental, and emotional wellbeing. This supports previous research that suggested interactions between mother and child during the early years is critical to developing healthy relationships and personal growth. 
In a study conducted in the New York prison system that measured the attachment between incarcerated mothers and their babies born in prison, Byrne, Goshin, and Joestl (2010) utilized the Ainsworth Strange Situation Procedure on 17 children who spent 13 months with their incarcerated mothers in a New York nursery program. The results revealed that despite a majority of the mothers not having formed a secure attachment in their own childhood, $71 \%$ of the babies were able to develop a secure attachment with their mothers while living in the prison nursery. This number is much higher than the general population, which is $65 \%$. This indicates that structure, safety, food, routine in correctional facility, and parental education helps to support those conditions for forming a secure attachment in infants born in prison. As a result, they can later be linked to children's prosocial behavior, better adaptation, and sound mental and physical health. This finding reveals that prison nurseries can effectively educate mothers, promote bonding, and provide a healthy trajectory for future development in children. At the same time, the prison nursery experience lasts long enough to allow infants an opportunity to develop secure attachment.

Since the few prison nursery programs that exist use many of the same criteria for selection and participation as New York (the oldest program), other states can have similar success if their programs are modeled after New York's program. Conversely, babies that are given over to foster care continue to drain and deplete limited state and federal resources. For example, experts in Nebraska argue that foster care for a prisoner's child costs an estimated \$20,000 annually. They also argue that the cost of incarcerating one female inmate annually is $\$ 39,472$ (see Nebraska Department of Correctional Services, 2010). Those who support prison nurseries and alternative programs argue that in the end, unless the criminal justice system comes to terms with the reality of pregnant women and mothers in prison, it will invariably have to address the aftermath of child abandonment and a lack of bonding owing to maternal incarceration. They argue that delinquency, crime, and intergenerational incarceration may be inevitable consequences of the failure to take progressive actions.

Prison nurseries hold the promise of improving the quality of life for mothers, as well as their children. While these groups are the primary concern of this investigation, we also discovered that when incarcerated mothers are not returned to prison, state and federal correctional systems save monies since they avoid using limited resources on recidivists' continued incarceration. Likewise, Campbell and Carlson (2012) suggest that the benefits of nursery programs include: reduced recidivism, a reduction in prison costs to taxpayers, improved bonding, and attachment between mother and infant, in addition to breaking the intergenerational cycle of incarceration.

While we advocate for more prison nurseries, this does not negate the importance of implementing community corrections programs. We argue that the government can use alternatives to provide opportunities for children to form a secure attachment (see Jbara, 2012; Gilad, 2013; McMillen, 2012). For example, some argue that judges should consider the status of parenthood as a mitigating factor in determining an appropriate sentence for pregnant offenders as well as women offenders who have young children (Boudin, 2011). As such, community-based correctional programs can punish the mother for her crime without disadvantaging her children who benefit from having access to her. These programs are less expensive than traditional incarceration and designed to help $t$ offenders reintegrate back into the community. They are not offered to every offender, especially not to violent offenders who would threaten the safety of the community. With that said, these programs allow offenders to serve their sentence in the community, but under proper supervision (Stohr \& Walsh, 2016).

While participating in community-based residential parenting programs, mothers can serve their sentence with their infant in a non-institutional setting. Villanueva (2009) argues these programs are not confining to mothers and their children born during the mothers' incarceration, but rather, they can leave residential facilities to receive perinatal and postpartum attention from a physician or attend to social service appointments and acquire programs noted for providing prosocial components (Villanueva, 2009; Walden, 2009). This allows them time to bond together so that mothers can learn parenting skills during this critical period of infant development. One example of this program is referred to as the Mothers and Infants Nurturing Together (MINT). It is used by the Federal Bureau of Prisons for eligible offenders who are pregnant at the time of commitment to a federal institution. It allows mothers to stay with their infants for an average of three months in a community setting. Afterwards, they are returned to the institution to complete their sentence. Moreover, MINT offers pregnant women and mothers programs such as childbirth or parenting (FBP, 2014).

While MINT provides opportunities to learn parenting skills, and time to bond with infants, the major benefits to infants may be lost where forming an attachment is concerned. In other words, three months may not be long enough for infants to form a secure attachment with mothers, unless the mothers' release date soon follows after the end of the program. This is critically important since children's attachment to a caregiver begins during the second half of the first year (see Bowlby, 1969; van Rosmalen et al., 2014). Notwithstanding, MINT programs last three months, with the exception of a program in West Virginia which currently allows mothers and infants to stay together for up to 12 months(Greenbrier Birthing Center, n.d.). Another concern of MINT is that it addresses babies born after the pregnant 
mother's commitment, and does not protect the rights of infants or toddlers born before the mother's incarceration.

Perhaps a more effective program for is the JusticeHome program in New York. Designed for mothers who plead guilty to a felony charge and face a minimum of six months of incarceration, the program allows mothers to remain at home to bond with their children while under the supervision of a case worker who visits and provides needed services. After the program if completed, charges are dismissed. It costs approximately $\$ 10,000-\$ 15,000$ and provides infants and toddlers an opportunity to form a secure attachment. Since it is not restricted to offenders being pregnant at the time of conviction, and upon completion, mothers and children can continue to build a life together (Berger, 2013; also see Fuchus, 2013).

\section{References}

Ainsworth, M. (1989). Attachment beyond infancy. American psychologist, 44(4), 709-716. https://doi.org/10.1037/0003-066X.44.4.709

Ainsworth, M. D. (1963). The development of infant-mother interaction among the Ganda. Determinants of Infant Behavior, 2, 67-112.

Ainsworth, M. D. (1967). Infancy in Uganda: Infant care and the growth of love. Baltimore, MD: John Hopkins University Press.

Ainsworth, M. D. (1979). Infant-mother attachment. American Psychologist, 34(10), 932-937. https://doi.org/10.1037/0003-066X.34.10.932

Ainsworth, M. D., \& Bell, S. M. (1969). Some contemporary patterns of mother-infant interaction in the feeding situation. In A. Ambrose (Ed.), Stimulation in early infancy (pp. 133-170). New York: Academic Press.

Ainsworth, M. D., \& Bell, S. M. (1970). Attachment, exploration, and separation: Illustrated by the behavior of one-year-olds in a strange situation. Child Development, 41(1), 49-67. https://doi.org/10.2307/1127388

Allen, D., \& Baker, B. (2013). Supporting mothering through breastfeeding for incarcerated women. Journal of Obstetric, Gynecologic, \& Neonatal Nursing, 42(1), 103-103. https://doi.org/10.1111/1552-6909.12203

Amnesty International. (2000). Pregnant and imprisoned in the United States. Birth, 27(4), 266-271. https://doi.org/10.1046/j.1523-536x.2000.00266.x

Anderson, S. E., Gooze, R. A., Lemeshow, S., \& Whitaker, R. C. (2012). Quality of early maternal-child relationship and risk of adolescent obesity. Pediatrics, 129, 132-140. https://doi.org/10.1542/peds.2011-0972

Anderson, S. E., \& Whitaker R. C. (2011). Attachment security and obesity in US preschool aged children. Archives of Pediatric and Adolescent Medicine, 165, 235-242. https://doi.org/10.1001/archpediatrics.2010.292

Arditti, J. A. (2012). Parental incarceration and the family. New York, NY: NYU Press.

Arditti, J., \& Few, A. (2008). Maternal distress and women's reentry into family and community life. Family Process, 47(3), 303-321. https://doi.org/10.1111/j.1545-5300.2008.00255.x

Bakermans-Kranenburg, M. J., \& Van IJzendoorn, M. H. (2009). The first 10,000 Adult Attachment Interviews: Distributions of adult attachment representations in clinical and non-clinical groups. Attachment \& Human Development, 11(3), 223-263. https://doi.org/10.1080/14616730902814762

Berger, J. (2013, May 8). Mothers convicted of felonies may get chance to stay out of prison. The New York Times. Retrieved from

http://www.nytimes.com/2013/05/09/nyregion/program-to-offer-alternative-to-jail-for-women-convicted-of-felonie s.html

Block, K. J., \& Potthest, M. J. (1998). Girl scouts beyond bars: Facilitating parent-child contact in correctional settings. Child Welfare, 77(5), 561-578.

Borelli, J. L., Goshin, L., Joestl, S., Clark, J., \& Byrne M. W. (2010). Attachment organization in a sample of incarcerated mothers: Distribution of classifications and associations with substance abuse history, depressive symptoms, perceptions of parenting competency and social support. Attachment \& Human Development, 12(4), 355-374. https://doi.org/10.1080/14616730903416971

Boudin, C. (2011). Children of incarcerated parents: The child's constitutional right to the family relationship. Journal of Criminal Law and Criminology, 101(1), 77-118.

Bowlby, J. (1969). Attachment and loss, Vol. 1: Attachment. New York, NY: Basic Books.

Bowlby, J. (1988). Attachment, communication, and the therapeutic process. A secure base: Parent-child attachment and 
healthy human development, 137-157.

Byrn, M. P., \& Ives, J. V., (2010). Which came first the parent or the child? Rutgers Law Review, 62, $305-343$.

Byrne, M. W., Goshin, L., \& Blanchard-Lewis, B. (2012). Maternal separations during the reentry years for 100 infants raised in a prison nursery. Family Court Review, 50(1), 77-90. https://doi.org/10.1111/j.1744-1617.2011.01430.x

Byrne, M. W., Goshin, L. S., \& Joestl, S. S. (2010). Intergenerational transmission of attachment for infants raised in a prison nursery. Attachment \& Human Development, 12(4), 375-393. https://doi.org/10.1080/14616730903417011

Campbell, J., \& Carlson, J. R. (2012). Correctional administrators' perceptions of prison nurseries. Criminal Justice and Behavior, 39(8), 1063-1074. https://doi.org/10.1177/0093854812441161

Carlson, J. R. (2001). Prison nursery 2000: A five year review of the prison nursery at the Nebraska Correctional Center for Women. Journal of Offender Rehabilitation, 33, 75-97. https://doi.org/10.1300/J076v33n03_05

Carlson, J. R. (2009). Prison nurseries: A pathway to crime-free futures. Corrections Compendium, 38(1), 17-22.

Carlson, L. A., Egeland, B., \& Sroufe, L. A. (2009). A prospective investigation of the development of borderline personality symptoms. Development and Psychopathology, 21, 1311-1334. https://doi.org/10.1017/S0954579409990174

Carson, E. A., \& Golinelli, D. (2013). Prisoners in 2012. Washington, DC: Bureau of Justice Statistics. Retrieved from http://www.bjs.gov/content/pub/pdf/p12tar9112.pdf

Cassidy, J. (2001). Truth, lies, and intimacy: An attachment perspective. Attachment \& Human Development, 3(2), 121-155. https://doi.org/10.1080/14616730110058999

Cassidy, J., Lichtenstein-Phelps, J., Sibrava, N. J., Thomas, C. L., \& Borkovec, T. D. (2009). Generalized anxiety disorder: Connections with self-reported attachment. Behavior Therapy, 40(1), 23-38. https://doi.org/10.1016/j.beth.2007.12.004

Cassidy, J, Ziv Y, Stupica B., Sherman L. J., Butler, H., Karfgin, A., Cooper, G., Hoffman, K.,T., \& Powell, B. (2010). Enhancing attachment security in the infants of women in a jail-diversion program. Attachment and Human Development, 12, 333-353. https://doi.org/10.1080/14616730903416955

Chambres, A. N. (2009). Impact of forced separation policy on incarcerated postpartum mothers. Policy, Politics, \& Nursing Practice, 10(3), 204-211. https://doi.org/10.1177/1527154409351592

Chemerinsky, E. (1993). Making the case for a constitutional right to minimum entitlements. Mercer Law Review, 44, 525-541.

Cho, R. M. (2009). Impact of maternal imprisonment on children's probability of grade retention. Journal of Urban Economics, 65, 11-23. https://doi.org/10.1016/j.jue.2008.09.004

Clarke, J. G., \& Adashi, E. Y. (2011). Perinatal care for incarcerated patients: A 25 -year-old woman pregnant in jail. JAMA, 305(9), 923-929. https://doi.org/10.1001/jama.2011.125

Craig, S. C. (2009). Historical review of mother and child programs for incarcerated women. Prison Journal, 89(1), 35-53. https://doi.org/10.1177/0032885508329768

Dailey, A. C. (2011). Children's constitutional rights. Minnesota Law Review, 95(6), 2099-2179.

Dallaire, D. H. (2007a). Incarcerated mothers and fathers: A comparison of risks for children and families. Family Relations, 56, 440-453. https://doi.org/10.1111/j.1741-3729.2007.00472.x

Dallaire, D. H. (2007b). Children with incarcerated mothers: Developmental outcomes, special challenges and recommendations. Journal of Applied Developmental Psychology, 28(1), 15-24. https://doi.org/10.1016/j.appdev.2006.10.003

DeBour, H. (2012). Prison nursery programs in other states. Office of Legislative Research, Connecticut. Retrieved from https://www.cga.ct.gov/2012/rpt/2012-R-0157.htm

Diamond, S. (2012). Prison nursery programs: Literature review and fact sheets for CT. Retrieved from https://www.cga.ct.gov/2013/JUDdata/Tmy/2013HB-06642-R000401-Sarah\%20Diamond\%20-\%20Director,\%20 Diamond\%20Research\%20Consulting-TMY.PDF

Dunn, E., \& Arbuckle, G. (2002). Impact of the LIFE program: An enhanced visitation program for the children of incarcerated parents.

Engstrom, M. (2008). Involving caregiving grandmothers in family intervention where mothers with substance use problems are incarcerated. Family Process, 47(3), 357-371. https://doi.org/10.1111/j.1545-5300.2008.00258.x 
Ezer, T. (2004). Positive right to protection for children. Yale Human Rights \& Development Law Journal, 7, 1-50.

Federal Bureau of Prisons. (2014). Legal resource guide to the Federal Bureau of Prisons. Retrieved from https://www.bop.gov/resources/pdfs/legal_guide.pdf

Federal Bureau of Prisons. (n.d.). Female offenders. Retrieved from https://www.bop.gov/inmates/custody_and_care/female_offenders.jsp

Fonagy, P., Lorenzini, N., Campbell, C., \& Luyten, P. (2014). Why are we interested in attachments? In P. Holmes \& S. Fairfield (Eds.), The Routledge handbook of attachment: Theory, 31-48. New York, NY: Routledge.

Fonagy, P., Target, M., \& Gergely, G. (2000). Attachment and borderline personality disorder: A theory and some evidence. Psychiatric Clinics of North America, 23(1), 103-122. https://doi.org/10.1016/S0193-953X(05)70146-5

Fonagy, P., Target, M, Gergely, G., Allen J. G., \& Bateman, A. W. (2003). The developmental roots of borderline personality disorder in early attachment relationships: A theory and some evidence. Psychoanalytic Inquiry, 23(3), 412-459. https://doi.org/10.1080/07351692309349042

Fuchus, E. (2013, August 14). Woman behind 'Orange is the new black' is pushing an unusual alternative to jailing women. Business insider. Retrieved from http://www.businessinsider.com/orange-is-the-new-blacks-piper-kerman-promotes-justicehome-2013-8

Gilad, M., \& Gat, T. (2013). U.S. v. My mommy: Evaluation of prison nurseries as a solution for children of incarcerated women. New York University Review of Law \& Social Change, 37(2), 371-402.

Glaze, L. E., \& Kaeble, D. (2014). Correctional populations in the United States, 2013. Washington, DC: Bureau of Justice Statistics. Retrieved from http://www.bjs.gov/content/pub/pdf/cpus13.pdf

Glaze, L. E., \& Maruschak, L. M. (2010). Parents in prison and their minor children. Bureau of Justice Statistics Special Report (Revised version). Washington, DC: Bureau of Justice Statistics. Retrieved from http://www.bjs.gov/content/pub/pdf/pptmc.pdf

Goshin, L. S., \& Byrne, M. W. (2009). Converging streams of opportunity for prison nurseries in the United States. Journal of Offender Rehabilitation, 48(4), 271-295. https://doi.org/10.1080/10509670902848972

Goshin, L. S., Byrne, M. W., \& Blanchard-Lewis, B. (2014). Preschool outcomes of children who lived as infants in a prison nursery. Prison Journal, 94(2), 139-158. https://doi.org/10.1177/0032885514524692

Greenbrier Birthing Center. (n.d.). The MINT program. Retrieved from http://www.greenbrierbirthingcenter.com/the-mint-program/

Greene, S., Haney, C., \& Hurtado, A. (2000). Cycles of pain: Risk factors in the lives of incarcerated mothers and their children. Prison Journal, 80(1), 3-23. https://doi.org/10.1177/0032885500080001001

Hancock, L. (2015). Program letting kids stay with mom inmates at prison remains unopened. Casper Star Tribune. Retrieved from http://trib.com/news/state-and-regional/govt-and-politics/program-letting-kids-stay-with-mom-inmates-at-prison-re mains/article_3f68fb53-f664-56c2-b9a7-d8c1a44fc304.html

Henkin, L. (1992). Human dignity and constitutional rights. In M. A. Meyer \& W. A. Parent (Eds.). The constitution of rights: Human dignity and American values (pp. 210-228). Ithaca, NY: Cornell University Press.

Hirschi, T. (1969). Causes of delinquency. Berkeley, CA: University of California Press.

Holmes, G. A. (1994). The tie that binds: The constitutional right of children to maintain relationships with parent-like individuals. Maryland Law Review, 53, 358-411.

Huang, K., Atlas, R., \& Parvez, F. (2012). The significance of breastfeeding to incarcerated pregnant women: An exploratory study. Birth, 39(2), 145-155. https://doi.org/10.1111/j.1523-536X.2012.00528.x

Huebner, B. M., \& Gustafson, R. (2007). The effect of maternal incarceration on adult offspring involvement in the criminal justice system. Journal of Criminal Justice, 35, 283-296. https://doi.org/10.1016/j.jcrimjus.2007.03.005

Imber-Black, E. (2008): Families after death, families after birth. Family Process, 47(4), 421-423. https://doi.org/10.1111/j.1545-5300.2008.00262.x

Indiana Department of Corrections. (n.d.). Wee Ones Nursery. Retrieved from http://www.in.gov/idoc/2857.htm

Jackson, J. S., \& Fasig, L. G. (2011). The parentless child's right to a permanent family. Wake Forest Law Review, 46(1), $1-44$.

James, D, \& Glaze, L. (2006). Mental health problems of prison and jail inmates. Washington, DC: Bureau of Justice 
Statistics. https://doi.org/10.1037/e557002006-001

Jbara, A. E. (2012). The price they pay: Protecting the mother-child relationship through the use of prison nurseries and residential parenting programs. Indiana Law Journal, 87(4), 1825-1846.

Jordon, E. (2012). Prison nurseries cut female inmates' risk of reoffending. The Gazette.

Kaeble, D., Glaze, L., Tsoutis, A., \& Minton, T. (2015). Correctional populations in the United States, 2014. Washington, DC: Bureau of Justice Statistics. Retrieved from http://www.bjs.gov/content/pub/pdf/cpus14.pdf

Kauffman, K. (2001). Mothers in prison. Corrections Today, 63(1), 62-66.

Kierkus, C. A., \& Baer, D. (2002). A social control explanation of the relationship between family structure and delinquent behavior. Canadian Journal of Criminology, 44(4), 425-458.

Kindred, K. P. (1996). God bless the child: Poor children, parens patrie, and a state obligation to provide assistance. Ohio State Law Journal, 57, 519-541.

Lee, A., \& Hankin, B. L. (2009). Insecure attachment, dysfunctional attitudes, and low self-esteem predicting prospective symptoms of depression and anxiety during adolescence. Journal of Clinical Child \& Adolescent Psychology, 38(2), 219-231. https://doi.org/10.1080/15374410802698396

Loper, A. B., Carlson, W., Levitt, L., \& Scheffel, K. (2009). Parenting stress, alliance, child contact and adjustment of imprisoned mothers and fathers. Journal of Offender Rehabilitation, 48(6), 483-503. https://doi.org/10.1080/10509670903081300

Luke, K. (2002). Mitigating the ill effects of maternal incarceration on women in prison and their children. Child Welfare, 81(6), 929-948.

Main, M., \& Solomon, J. (1986). Discovery of a new, insecure-disorganized/disoriented attachment pattern. In T. B. Brazelton \& M. Yogman (Eds.), Affective development in infancy (pp. 95-124). Norwood, NJ: Ablex.

Makariev, D. W., \& Shaver, P. R. (2010). Attachment, parental incarceration and possibilities for intervention: An overview. Attachment \& Human Development, 12(4), 311-331. https://doi.org/10.1080/14751790903416939

Maruschak, L. (2006). Medical problems of jail inmates. Washington, DC: Bureau of Justice Statistics. https://doi.org/10.1037/e500022007-001

Maruschak, L. (2008). Medical problems of prisoners. Washington, DC: Bureau of Justice Statistics. https://doi.org/10.1037/e448112008-001

McLaughlin, J. H. (2009). The fundamental truth about best interests. Saint Louis University Law Journal, 54, 113-165.

McMillen, M. (2012). I need to feel your touch: Allowing newborns and infants contact visitation with jailed parents. University of Illinois Law Review, 2012(5), 1811-1854.

Michelman, F. I. (1969). Foreword: On protecting the poor through the Fourteenth Amendment. Harvard Law Review, 83(1), 7-59. https://doi.org/10.2307/1339772

Mikulincer, M., \& Shaver, P. R. (2007). Boosting attachment security to promote mental health, prosocial values, and inter-group tolerance. Psychological Inquiry, 18(3), 139-156. https://doi.org/10.1080/10478400701512646

Miller, K. M. (2006). The impact of parental incarceration on children: An emerging need for effective interventions. Child and Adolescent Social Work Journal, 23(4), 472-486. https://doi.org/10.1007/s10560-006-0065-6

Mineka, S., Watson, D., \& Clark, L. A. (1998). Comorbidity of anxiety and unipolar mood disorders. Annual Review of Psychology, 49, 377-419. https://doi.org/10.1146/annurev.psych.49.1.377

Morash, M., \& Schram, P. J. (2002). The prison experience: Special issues of women in prison. Prospect Heights, IL: Waveland.

Murray, J., \& Farrington, D. P. (2005). Parental imprisonment: effects on boys' antisocial behaviour and delinquency through the life-course. Journal of Child Psychology and Psychiatry, 46(12), 1269-1278. https://doi.org/10.1111/j.1469-7610.2005.01433.x

Murray, J., \& Murray, L. (2010). Parental incarceration, attachment and child psychopathology. Attachment \& Human Development, 12(4), 289-309. https://doi.org/10.1080/14751790903416889

Myers, B. J., Smarsh, T. M., Amlund-Hagen, K., \& Kennon, S. (1999). Children of incarcerated mothers. Journal of Child and Family Studies, 8(1), 11-25. https://doi.org/10.1023/A:1022990410036

Nebraska Department of Correctional Services. (2010). 36th annual report and statistical summary. Lincoln, NE. 
Retrieved from http://www.corrections.nebraska.gov/pdf/annualreports/2010\%20NDCS\%20Annual\%20Report.pdf

Nolte, T., Guiney, J., Fonagy, P., Mayes, L. C., \& Luyten, P. (2011). Interpersonal stress regulation and the development of anxiety disorders: an attachment-based developmental framework. Frontiers in Behavioral Neuroscience, 5(55), 1-21. https://doi.org/10.3389/fnbeh.2011.00055

Poehlmann, J. (2005a). Representations of attachment relationships in children of incarcerated mothers. Child Development, 76(3), 679-696. https://doi.org/10.1111/j.1467-8624.2005.00871.x

Poehlmann, J. (2005b). Children's family environments and intellectual outcomes during maternal incarceration. Journal of Marriage and Family, 67(5), 1275-1285. https://doi.org/10.1111/j.1741-3737.2005.00216.x

Poehlmann, J. (2005c). Incarcerated mothers' contact with children, perceived family relationships, and depressive symptoms. Journal of Family Psychology, 19(3), 350-357. https://doi.org/10.1037/0893-3200.19.3.350

Poehlmann, J., Shlafer, R. J., Maes, E., \& Hanneman, A. (2008). Factors associated with young children's opportunities for maintaining family relationships during maternal incarceration. Family Relations, 57, 267-280. https://doi.org/10.1111/j.1741-3729.2008.00499.x

Puig, J., Englund, M. M., Simpson, J. A., \& Collins, W. A. (2013). Predicting adult physical illness from infant attachment: A prospective longitudinal study. Health Psychology: Official Journal of the Division of Health Psychology, 32(4), 409-417. https://doi.org/10.1037/a0028889

Richie, B. E. (2002). The social impact of mass incarceration on women. In M. Mauer \& M. Chesney-Lind (Eds.), Invisible punishment: The collateral consequences of mass imprisonment (pp. 136-149). New York: New Press.

Sandifer, J. L. (2008). Evaluating the efficacy of a parenting program for incarcerated mothers. Prison Journal, 8(3), 423-445. https://doi.org/10.1177/0032885508322533

Shamai, M., \& Kochal, R. (2008). Motherhood starts in prison: The experiences of motherhood among women in prison. Family Process, 47(3), 323-340. https://doi.org/10.1111/j.1545-5300.2008.00256.x

Shannon, S. K., \& Abrams, L. S. (2007). Juvenile offenders as fathers: Perceptions of fatherhood, crime, and becoming an adult. Families in Society, 88(2), 183-191. https://doi.org/10.1606/1044-3894.3616

Shapiro, M. H. (2002). Constitutional adjudication and standards of review under pressure from biological technologies. Health Matrix, 11, 351-486.

Shlafer, R. J., \& Poehlmann, J. (2010). Attachment and caregiving relationships in families affected by parental incarceration. Attachment \& Human Development, 12(4), 395-415. https://doi.org/10.1080/14616730903417052

Siegel, D. J. (2002). What do parents need to know about brain development and interpersonal experiences with their children? Gifted Education Communicator, 33(2).

Siegel, D. J. (2012). Developing mind: How relationships and the brain interact to shape who we are (2nd ed.). New York, NY: Guilford.

Sipes, L. A. (2012). Statistics on women offenders. Retrieved from http://www.corrections.com/news/article/30166-statistics-on-women-offenders

Stohr, M. K., \& Walsh, A. (2016). Corrections: The essential (2nd ed.). Thousand Oaks, CA: Sage.

The Sentencing Project. (2012). Incarcerated women. Retrieved from http://sentencingproject.org/doc/publications/cc_Incarcerated_Women_Factsheet_Dec2012final.pdf

The Sentencing Project. (2015). Fact sheet: Trends in U.S. corrections. Retrieved from http://sentencingproject.org/wp-content/uploads/2016/01/Trends-in-US-Corrections.pdf

Van IJzendoorn, M. H., Juffer, F., \& Duyvesteyn, M. G. (1995). Breaking the intergenerational cycle of insecure attachment: A review of the effects of attachment-based interventions on maternal sensitivity and infant security. Journal of Child Psychology and Psychiatry, 36(2), 225-248. https://doi.org/10.1111/j.1469-7610.1995.tb01822.x

Van Rosmalen, L., Van Ijzendoorn, M. H., \& Bakermans-Kranenburg, M. J. (2014). ABC+D of attachment theory: The Strange Situation Procedure as the gold standard of attachment assessment. In P. Holmes \& S. Farnfield (Eds.), The Routledge handbook of attachment: Theory, 11-30. New York, NY: Routledge.

Villanueva, C. K. (2009). Prison nursery programs a growing trend in women's prisons. Women's Prison Association. Retrieved from http://www.corrections.com/articles/21644-prison-nursery-programs-a-growing-trend-in-women-s-prisons

Villanueva, C. K., From, S., \& Lerner, G. (2009). Mothers, infants, and imprisonment: A national look at prison nurseries 
and community-based alternatives. New York, NY: Women's Prison Association.

Walden, R. (2009). New report released on prison nurseries. Retrieved from http://www.ourbodiesourselves.org/2009/05/new-report-released-on-prison-nurseries/

Waters, E., Hamilton, C. E., \& Weinf, N. S. (2000). The stability of attachment security from infancy to adolescence and early adulthood: General introduction. Child Development, 71(3), 678-683. https://doi.org/10.1111/1467-8624.00175

Weinfield, N. S., Sroufe, L. A., Egeland B., \& Carlson, E. (2008). Individual differences in infant-caregiver attachment: Conceptual and empirical aspects of security. In J. Cassidy \& P. R. Shaver (Eds.), Handbook of attachment: Theory, research, and clinical applications (2nd ed.) (pp. 78-101). New York, NY: Guilford.

Yagar, S. (2015, July/August). Prison born. The Atlantic. Retrieved from http://www.theatlantic.com/magazine/archive/2015/07/prison-born/395297/

Zou, J. J. (2014). Access denied: Pregnant inmates struggle to gain entry to prison nursery programs. The New York World. Retrieved from http://www.thenewyorkworld.com/2014/10/20/prison-nursery/

\section{Cases Cited}

Bowers v. DeVito, 686 F.2d 616 (7th Cir. 1982).

Carey v. Population Service International, 431 U.S. 678 (1977).

Castle Rock v. Gonzales, 545 U.S. 748 (2005).

Cruzan v. Director, Missouri Department of Health, 497 U.S. 261 (1990).

Dandridge v. Williams, 397 U.S. 471 (1970).

DeShaney v. Winnebago County Department of Social Services, 489 U.S. 189 (1989).

Griswold v. Connecticut, 382 U.S. 479 (1965).

Ingraham v. Wright, 430 U.S. 651 (1977).

James v. Valtierra, 402 U.S. 137 (1971).

Loving v. Virginia, 388 U.S. 1 (1967).

Lawrence v. Texas, 539 U.S. 558 (2003).

Meyer v. Nebraska, 262 U. S. 390 (1923).

Moore v. East Cleveland, 431 U.S. 494 (1977).

Obergefell v. Hodges, 135 S. Ct. 2584 (2015).

Overton v. Bazzetta, 539 U.S. 126 (2002).

Parham v. J.R., 442 U.S. 584 (1979).

Pierce v. Society of Sisters, 268 U.S. 510 (1925).

Planned Parenthood v. Casey, 505 U.S. 833 (1992).

Riggins v. Nevada, 504 U.S. 127 (1992).

Roe v. Wade, 410 U.S. 113 (1973).

San Antonio Independent School District v. Rodriguez, 411 U.S. 1 (1973).

Sell v. United States, 539 U.S. 166 (2003).

Turner v. Safley, 482 U.S. 78 (1987).

Washington v. Harper, 494 U.S. 210 (1990).

Wisconsin v. Yoder, 406 U.S. 205 (1972).

Youngberg v. Romeo, 457 U.S. 307 (1982).

\section{Copyrights}

Copyright for this article is retained by the author(s), with first publication rights granted to the journal.

This is an open-access article distributed under the terms and conditions of the Creative Commons Attribution license which permits unrestricted use, distribution, and reproduction in any medium, provided the original work is properly cited. 